\title{
The role of progesterone in prevention of preterm birth
}

This article was published in the following Dove Press journal:

International Journal of Women's Health

30 July 2009

Number of times this article has been viewed

Jodie M Dodd

Caroline A Crowther

Discipline of Obstetrics and Gynaecology, The University of Adelaide, Adelaide, South Australia, Australia
Correspondence: Jodie M Dodd Discipline of Obstetrics and Gynaecology, The University of Adelaide, Women's and Children's Hospital, 72 King William Road, North Adelaide, South Australia 5006, Australia

$\mathrm{Tel}+61881617619$

Fax +61881617652

Email jodie.dodd@adelaide.edu.au
Abstract: Preterm birth continues to provide an enormous challenge in the delivery of perinatal health care, and is associated with considerable short and long-term health consequences for surviving infants. Progesterone has a role in maintaining pregnancy, by suppression of the calcium-calmodulin-myosin light chain kinase system. Additionally, progesterone has recognized anti-inflammatory properties, raising a possible link between inflammatory processes, alterations in progesterone receptor expression and the onset of preterm labor. Systematic reviews of randomized controlled trials evaluating the use of intramuscular and vaginal progesterone in women considered to be at increased risk of preterm birth have been published, with primary outcomes of perinatal death, preterm birth $<34$ weeks, and neurodevelopmental handicap in childhood. Eleven randomized controlled trials were included in the systematic review, involving 2714 women and 3452 infants, with results presented according to the reason women were considered to be at increased risk of preterm birth. While there is a potential beneficial effect in the use of progesterone for some women considered to be at increased risk of preterm birth, primarily in the reduction in the risk of preterm birth before 34 weeks gestation, it remains unclear if the observed prolongation of pregnancy translates into improved health outcomes for the infant.

Keywords: progesterone, preterm birth, systematic review, randomized trial

\section{The extent of preterm birth}

Preterm birth, is defined by the World Health Organisation as birth prior to 37 completed weeks of gestation, ${ }^{1}$ and continues to provide an enormous challenge in the delivery of perinatal health care, estimated to affect approximately 13 million births annually worldwide. ${ }^{2}$ The incidence of preterm birth is variably reported between $5 \%$ and $11 \%$ of all births, ${ }^{3,4}$ and its prevention continues to remain elusive, with many reports indicating an increase in the prevalence of preterm birth over recent years. ${ }^{5-7}$ Many factors have been implicated, including an increase in maternal age and use of assisted reproductive techniques, with resultant increases in the risk of multiple pregnancy, ${ }^{8-10}$ increasing maternal body mass index and the influence of obesity, ${ }^{11}$ continued maternal smoking during pregnancy, ${ }^{12,13}$ and infection. However, recent reports from Denmark ${ }^{6}$ and Australia ${ }^{7}$ demonstrate an increase in the occurrence of spontaneous preterm birth among women considered to be at low risk of $22 \%$ and $12 \%$ respectively.

\section{Health consequences of preterm birth}

Infants born preterm are over 40 times more likely to die during the neonatal period than are term infants, ${ }^{14,15}$ and while the risk is greatest for infants born at earlier gestational 
ages, this increased risk of mortality persists even for infants born between 32 and 36 weeks gestation. ${ }^{16}$ While preterm birth contributes a relatively small proportion of total births, it is associated with in excess of $70 \%$ of the total perinatal mortality in developed countries, when excluding deaths related to congenital anomalies. ${ }^{8,12,17}$

For surviving infants, there are significant health implications, particularly in relation to immature lung development, with respiratory distress syndrome being a major consequence of preterm birth, ${ }^{18}$ and the most significant cause of early neonatal mortality and morbidity. ${ }^{16}$ Infants often require respiratory support, with a significant proportion requiring mechanical ventilation. Up to $20 \%$ of surviving infants remain dependent on oxygen therapy 28 days after birth, with $25 \%$ diagnosed with chronic lung disease. ${ }^{19}$ Other well-documented health complications include intraventricular hemorrhage and periventricular leukomalacia, with implications for ongoing cerebral dysfunction, ${ }^{20}$ infectious morbidity, ${ }^{21}$ and specific neonatal conditions associated with prematurity, including retinopathy of prematurity ${ }^{22}$ and necrotising enterocolitis. ${ }^{23}$ Infants continue to be at increased risk of hospitalization in the first year of life. ${ }^{24,25}$ In the longer-term, children have ongoing risks of motor and sensory impairment, ${ }^{26,27}$ and subsequent handicap, including cerebral palsy. ${ }^{28}$ Additionally, infants born preterm have well recognized learning difficulties, ${ }^{29-33}$ behavioral problems, ${ }^{32,34-36}$ and continue to be at an educational disadvantage that persists into adulthood. ${ }^{37,38}$

\section{Economic costs of preterm birth}

The immediate and longer-term monetary costs related to preterm birth and neonatal intensive care unit admissions are considerable. Figures from the United States in 1990, estimated a weekly cost of approximately \$US10,000 per preterm baby, increasing considerably with earlier gestational age at birth. ${ }^{39}$ More recent US figures suggest the annual cost of preterm birth has escalated to in excess of US\$26 billion, ${ }^{5}$ with the costs being greatest for infants born at earlier gestational ages. ${ }^{40}$

These figures relate primarily to intensive care unit costs, without consideration of costs related to ongoing care. Using data from Oxfordshire and West Berkshire, United Kingdom, Petrou and colleagues have compared the cumulative use and cost of hospitalisation to age 5 years, according to gestational age at birth. ${ }^{25}$ The duration of hospital admissions for infants born prior to 28 weeks gestation was 85 times greater when compared with infants born at term, with an adjusted mean cost difference of \$US 22,789 per infant over the first 5 years of life. ${ }^{25}$ Infants born between 28 and 31 weeks gestation had 16 times longer duration of hospitalisation, with an adjusted mean cost difference of \$US18,654 per infant over the first 5 years of life. ${ }^{25}$

Clements and colleagues have conducted populationbased estimates of the costs related to infant and toddler development services utilised by preterm infants in the first three years of life. ${ }^{41}$ Total programme costs approached \$US 66 million, with the mean cost per infant \$US857. ${ }^{41}$ Costs varied considerably with gestational age at birth, increasing from \$US725 per infant born at term, to \$US1,578 per infant born between 32 and 36 weeks gestation, to \$US5,393 per infant born between 24 and 31 weeks gestation. ${ }^{41}$

These economic estimates relate primarily to intensive care unit costs, without consideration of costs related to ongoing care, or of the enormous emotional and personal costs for families and individuals who are born preterm.

\section{Recurrence of preterm birth}

The "cause" of preterm birth is multifactorial, with social, psychological, and biological factors playing a role. ${ }^{42-45}$ The most significant and consistently identified risk factor for preterm birth is a woman's history of previous preterm birth. ${ }^{46-54}$ Estimates suggest the rate of recurrent preterm birth in this group of women is $22.5 \%,{ }^{55}$ a 2.5 times increased relative risk when compared with women with no previous spontaneous preterm birth. ${ }^{56}$ For women with a history of a single preterm birth, the recurrence risk in a subsequent pregnancy is approximately $15 \%$, increasing to $32 \%$ where there have been two previous preterm births. ${ }^{57}$ Approximately $30 \%$ of women who give birth between 20 and 31 weeks gestation will birth prior to 37 weeks in a subsequent pregnancy, ${ }^{47}$ and for approximately $10 \%$ of these women, the preterm birth will occur at a similar gestational age..$^{47,54,58}$ In up to $50 \%$ of cases of preterm birth, the cause is spontaneous onset of labor or preterm premature rupture of membranes (PPROM). ${ }^{17,59-61}$

\section{The role of progesterone in preterm labor}

The exact mechanism of the onset of both term and preterm labor in humans is a complex interaction of many different hormonal pathways, culminating in co-ordinated uterine contractile activity, mediated by the production of prostaglandins. ${ }^{62-64}$ Before birth, coordinated uterine activity is associated with connective tissue changes resulting in cervical ripening and dilatation. ${ }^{64}$ Progesterone has an essential role in maintaining pregnancy, ${ }^{65-67}$ primarily through 
establishing uterine quiescence. ${ }^{68,69}$ This is achieved through suppression of the calcium-calmodulin-myosin light chain kinase system, reducing calcium flux and altering the resting potential of smooth muscle. ${ }^{64,66}$

There is considerable debate about the relationship between progesterone withdrawal ${ }^{70}$ and the onset of labor. ${ }^{71}$ In humans, the progesterone receptor (PR) has two major subtypes PR-A and PR-B. Binding of progesterone to PR-A, the short form of the receptor, not thought to be associated with intra-cellular pathway mechanisms, prevents the actions of progesterone mediated by PR-B. ${ }^{71}$ An increase in the myometrial PR-A to PR-B expression ratio occurs at the onset of labor at term, resulting in an increase in myometrial PR-A, and in effect a functional withdrawal of progesterone, ${ }^{71,72}$ with increasing sensitivity to contractile stimuli. ${ }^{65,67,73,74}$ Prostaglandins produced prior to the onset of labor, also act to increase the PR-A/PR-B expression ratio, and therefore the potential to initiate a functional withdrawal of progesterone. ${ }^{67}$ In many animals the onset of labor is associated with a decrease in progesterone concentrations, ${ }^{62,64,65,75}$ but this has not been shown to occur in women before term or preterm birth, with no apparently detectable changes to circulating steroid hormone levels evident. ${ }^{64,65,67,76,77}$

\section{Progesterone as an anti- inflammatory agent}

In both term and preterm labor, there is evidence of an increase in inflammatory markers tumor necrosis factor (TNF) -alpha, interleukin-1 (IL-1) and interleukin-6 (IL-6), and down-regulation of the anti-inflammatory interleukin-10 (IL-10) ${ }^{78,79}$ Inflammatory cytokines may alter enzyme expression, increasing prostaglandin production prior to the onset of labor. ${ }^{78,79}$ These maternal inflammatory mediators may then interact at the feto-placental unit, precipitating preterm birth. ${ }^{80}$ In particular, inflammatory cytokines interleukin-1 and TNF-alpha act to increase prostaglandin production, while both IL-10 and progesterone have a negative effect on prostaglandin production. ${ }^{63}$

It is in this context that progesterone may exert its antiinflammatory properties, raising a possible link between inflammatory process, alterations in progesterone receptor expression and the onset of preterm labor. ${ }^{81}$ While it has been postulated that the effect of progesterone on preterm birth is related to its anti-inflammatory properties, the specific mechanism of action remains unclear. A number of investigators have developed models of inflammation in pregnant animals and examined the effect of pre-treatment with progesterone on inflammatory mediators.
Elovitz and colleagues have developed a mouse model of intra-uterine inflammation with intrauterine injection of lipopolysaccharide (LPS). ${ }^{82-84}$ In these experiments, pre-treatment with progesterone was associated with suppression of activation of contraction-associated genes and inflammatory mediators, as well as prevention of the cervical ripening response to intrauterine inflammation. ${ }^{82}$ Pre-treatment with progesterone was associated with a reduction in preterm labor and preserved fetal viability in the mouse. ${ }^{82,83}$ In a subsequent experiment, the influence of progesterone on Toll-like receptors was evaluated. ${ }^{84}$ Toll-like receptors are involved in both the initiation and modulation of the inflammatory response, and regulation of these receptors may be one mechanism whereby intrauterine inflammation mediates the onset of labor, and therefore modifiable by the administration of progesterone. ${ }^{84}$ Pre-treatment of mice with progesterone prior to the creation of an intra-uterine inflammatory environment, was associated with a decrease in the LPS induced up-regulation of receptors in both the cervix and placenta. ${ }^{84}$ The authors concluded that this may be a potential mechanism whereby progesterone acts to reduce the risk of preterm birth. ${ }^{82-84}$

Other investigators ${ }^{85,86}$ have evaluated the antiinflammatory effect of progesterone at the feto-placental unit. Placental chorionic plate arteries were exposed to either lipopolysaccharide alone or in combination with progesterone. Exposure to LPS alone was associated with an increase in the production of the inflammatory cytokine IL-6. ${ }^{85,86}$ Pre-treatment of the arteries with progesterone was associated with reduced production of IL-6 after LPS exposure, although there was no demonstrable effect on the concentrations of TNF-alpha or IL-10. ${ }^{85,86}$ Similarly, exposure to progesterone was associated with a reduction in both fetal and maternal mononuclear cell expression of IL-6 after exposure to LPS, again suggesting these cell populations as possible targets for the anti-inflammatory effects of progesterone, and a potential mechanism for the observed reduction in preterm birth following progesterone..$^{85,86}$

\section{Pharmacokinetics of progesterone by route of administration}

Current information about the pharmacokinetics of progesterone relates to its use in assisted reproduction, ${ }^{87-90}$ in menopausal ${ }^{91}$ and post-menopausal women, ${ }^{8892}$ and in women with endometrial carcinoma. ${ }^{93}$ These studies indicate blood progesterone concentrations following vaginal administration to be lower than after intramuscular administration. ${ }^{89,90}$ There are few data available to inform the optimal route of 
administration in women in later pregnancy. For $100 \mathrm{mg}$ vaginal progesterone pessaries the peak blood concentrations are obtained 3 to 8 hours after vaginal administration, due to avoidance of first pass hepatic metabolism. In blood, progesterone is $96 \%$ to $99 \%$ protein bound, mainly to albumin. While there may be advantages in the use of intramuscular progesterone in terms of increased blood concentrations, such preparations are not available in many countries world-wide.

\section{Safety of progesterone}

Natural progesterone has been used in pregnancy without demonstrated effect on fetal development or on the risk of congenital anomalies. ${ }^{94,95}$ Information from animal studies suggests that progesterone influences fetal behavior in sheep, ${ }^{96}$ with increased concentrations suppressing activity and arousal states. ${ }^{97,98}$ Much of the information relating to childhood outcomes dates to more than 30 years ago, utilising a variety of progestogenic agents. ${ }^{99-102}$ Recognized maternal side-effects related to progesterone therapy include headache, nausea, breast tenderness, and coughing.

\section{Is there clinical evidence to suggest a role for progesterone in preventing preterm birth?}

The administration of progesterone as a therapeutic agent for the prevention of preterm birth dates to the early 1960s, ${ }^{103}$ with considerable renewed interest in its use following recent reports of randomized controlled trials published first in 2003. ${ }^{104,105}$

There have been several systematic reviews of randomized controlled trials evaluating the use of both intramuscular and vaginal progesterone in women considered to be at increased risk of preterm birth published, ${ }^{106-111}$ in addition to many narrative reviews. ${ }^{112-115}$

In considering the effects of progesterone for preterm birth, the most recent systematic reviews will be considered in more detail. ${ }^{108,109}$ The prespecified primary outcomes were perinatal death, preterm birth $<34$ weeks, and neurodevelopmental handicap in childhood. ${ }^{108,109}$ Eleven randomized controlled trials were included in the systematic review, involving 2714 women and 3452 infants, with results presented according to the reason women were considered to be at increased risk of preterm birth. ${ }^{108,109}$ Characteristics of these studies are presented in Table 1.

For women with a past history of spontaneous preterm birth, progesterone was associated with no significant difference in perinatal death (3 studies, 1114 participants, relative risk [RR] $0.65,95 \%$ confidence interval [CI] 0.38 to 1.11 ); but a reduction in preterm birth prior to 34 weeks (1 study; 142 women; RR 0.15 ; $95 \%$ CI 0.04 to 0.64 ; number needed to treat (NNT) 7; 95\% CI 4 to 17) (Table 2). ${ }^{108,109}$ While there was a significant reduction in the risk of infant birth-weight less than $2500 \mathrm{~g}$ (2 studies, 501 infants, RR $0.64,95 \%$ CI 0.49 to 0.83 ), there were no other differences identified between the two treatment groups for secondary neonatal outcomes. It is important to bear in mind that the combined sample size of 1329 infants is underpowered to reliably detect differences of clinical relevance in markers of neonatal morbidity and mortality. The report by Northen ${ }^{116}$ details the 2 year follow-up of 278 participants from the Meis randomized trial. ${ }^{105}$ While only $60 \%$ of infants were available for follow-up, this study did not identify statistically significant differences between the progesterone and placebo treatment groups in the risk of childhood developmental delay (RR 0.97; 95\% CI 0.55 to 1.73 ). ${ }^{108,109}$

Information about the optimal route of progesterone administration is insufficient. Of particular note, the largest study to date using vaginal progesterone gel identified no benefit for women with a previous preterm birth. ${ }^{117}$ However, the results of ongoing randomized trials assessing the role of intramuscular ${ }^{118}$ and vaginal ${ }^{119,120}$ progesterone in women with a history of spontaneous preterm birth will contribute information about the role of progesterone in this group of women (Table 3).

For women considered to be at increased risk of preterm birth due to the identification of a short cervix on ultrasound, progesterone was associated with no significant difference in perinatal death (1 study, 274 participants, RR $0.38,95 \%$ CI 0.10 to 1.40 ); but a significant reduction in preterm birth before 34 weeks ( 1 study; 250 women; RR $0.58 ; 95 \%$ CI 0.38 to 0.87 ; NNT 7 ; $95 \%$ CI 4 to 25$).{ }^{108,109}$ While the study reported a significant reduction in the risk of neonatal sepsis, ${ }^{121}$ the sample size of 250 is underpowered to reliably detect differences in neonatal outcomes. There is a single registered randomized trial evaluating the use of intramuscular ${ }^{122}$ progesterone in nulliparous women with a short cervix identified on transvaginal ultrasound and this will contribute important information when completed.

The role of progesterone to prevent preterm birth in women with a multiple pregnancy is far less certain. Two randomized trials were included evaluating the use of progesterone in women with a multiple pregnancy. ${ }^{123,124}$ The primary outcome for the Rouse study ${ }^{124}$ was a composite of birth before 35 weeks gestation or death, with no statistically significant differences identified between the 


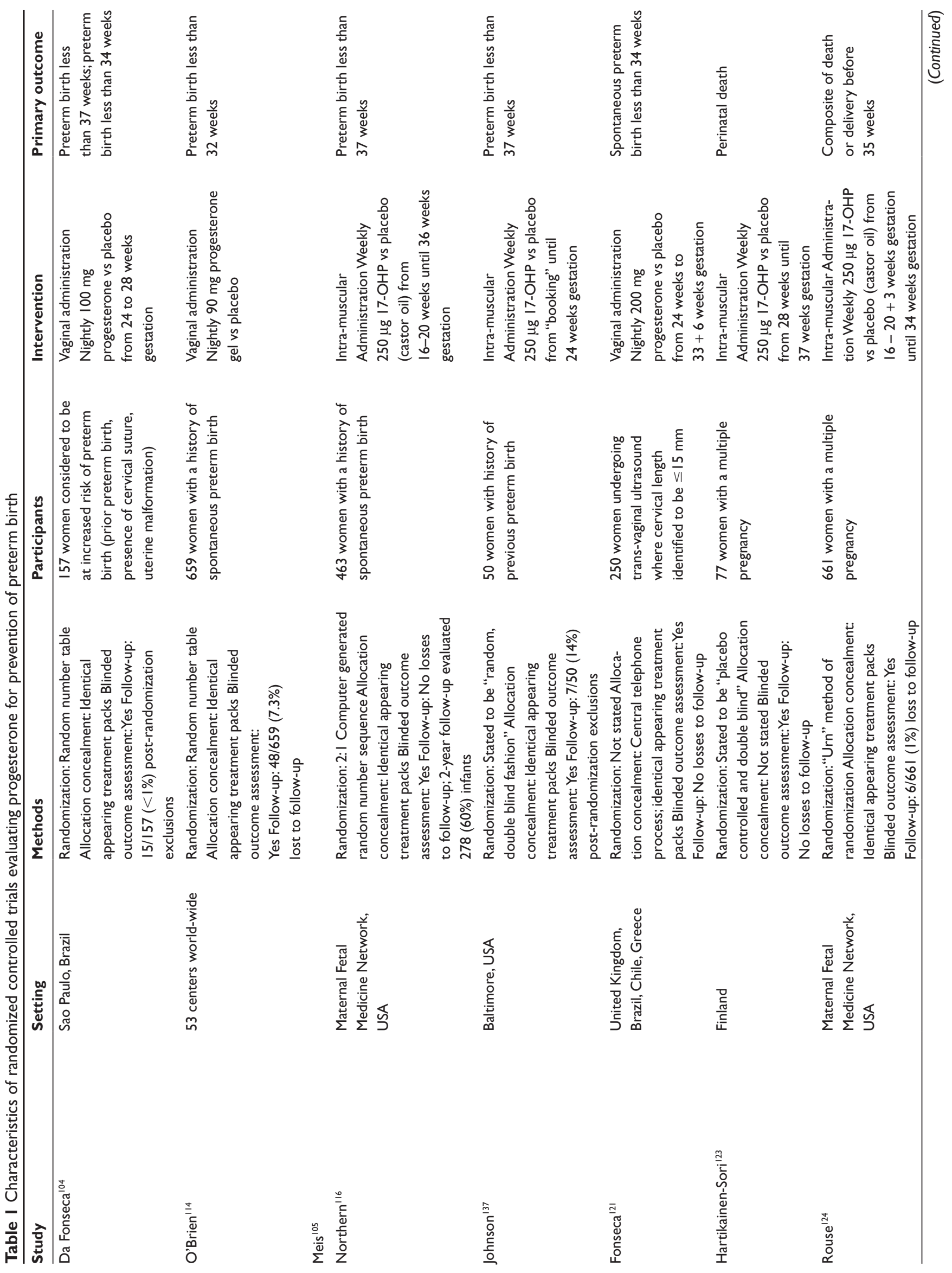




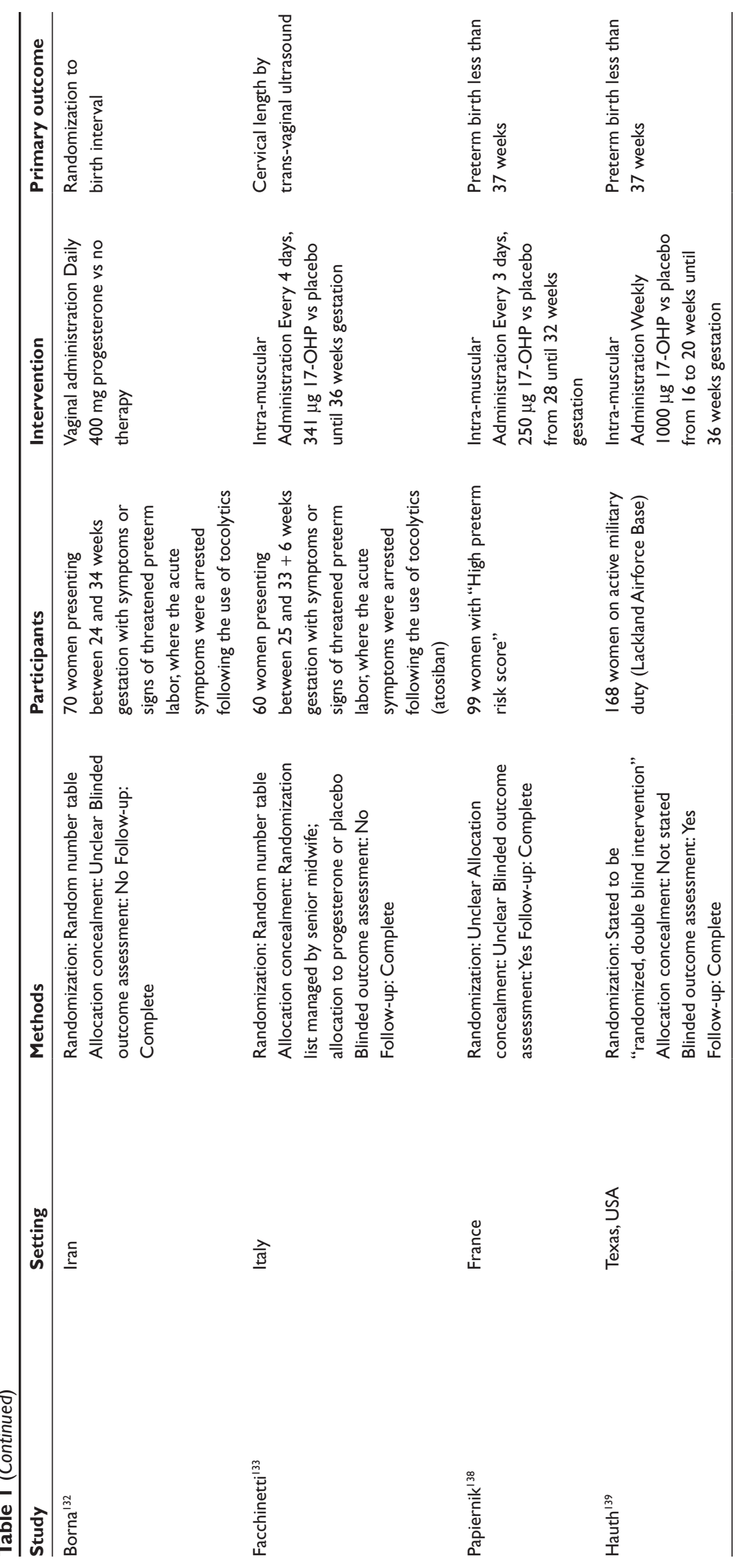


Table 2 Summary findings reported in systematic reviews ${ }^{105,106}$ for primary outcomes by reason at risk of preterm birth

\begin{tabular}{|c|c|c|c|c|c|}
\hline $\begin{array}{l}\text { Reason at risk of } \\
\text { preterm birth }\end{array}$ & Outcome & $\begin{array}{l}\text { Number of } \\
\text { studies }\end{array}$ & $\begin{array}{l}\text { Number of } \\
\text { participants }\end{array}$ & $\begin{array}{l}\text { Relative } \\
\text { risk }\end{array}$ & $\begin{array}{l}95 \% \text { confidence } \\
\text { interval }\end{array}$ \\
\hline \multirow[t]{3}{*}{ Previous preterm birth } & Perinatal death & 3 & 1114 & 0.65 & 0.38 to 1.11 \\
\hline & $\begin{array}{l}\text { Preterm birth less } \\
\text { than } 34 \text { weeks }\end{array}$ & 1 & 142 & 0.15 & 0.04 to 0.64 \\
\hline & $\begin{array}{l}\text { Childhood } \\
\text { developmental delay }\end{array}$ & I & 275 & 0.97 & 0.55 to 1.73 \\
\hline Ultrasound identified & Perinatal death & I & 274 & 0.38 & 0.10 to 1.40 \\
\hline short cervix & $\begin{array}{l}\text { Preterm birth less } \\
\text { than } 34 \text { weeks }\end{array}$ & 1 & 250 & 0.58 & 0.38 to 0.87 \\
\hline Multiple pregnancy & Perinatal death & 1 & 154 & 1.95 & 0.37 to 10.33 \\
\hline $\begin{array}{l}\text { Following symptoms } \\
\text { or signs of threatened } \\
\text { preterm labor }\end{array}$ & $\begin{array}{l}\text { Nil primary } \\
\text { outcomes reported }\end{array}$ & & & & \\
\hline "Other" reason & Perinatal death & 2 & 264 & 1.10 & 0.23 to 5.29 \\
\hline
\end{tabular}

progesterone and placebo groups. The only pre-specified primary outcome was perinatal death, with no significant differences identified (1 study, 154 participants, RR 1.95, 95\% CI 0.37 to 10.33 ). While the use of progesterone was associated with a reduction in the use of antenatal tocolysis, ${ }^{124}$ there were no differences identified for other secondary infant and maternal health outcomes. The role of intramuscular ${ }^{125-127}$ and vaginal ${ }^{128-131}$ progesterone in women with a multiple pregnancy is the subject of several ongoing randomized studies.

Two studies were included in the systematic review where women presenting following treatment for threatened preterm labor received progesterone therapy for the remainder of their pregnancy, ${ }^{132,133}$ but none of the pre-specified primary outcomes were reported. ${ }^{108,109}$ Neither study utilized a placebo, and outcome assessors were not blinded, increasing the potential for bias. An ongoing trial assessing the role of vaginal progesterone ${ }^{134}$ in women presenting with symptoms or signs of threatened preterm labor will contribute information in the future.

For women with "other" risk factors that were considered to increase the risk of preterm birth, progesterone was not associated with a significant difference in perinatal death (2 studies, 264 participants, RR 1.10, 95\% CI 0.23, 5.29). ${ }^{108,109}$ No other statistically significant differences were identified for the outcomes reported.

While there is information available from randomized trials suggesting that progesterone therapy may be beneficial for some women considered to be at increased risk of preterm birth, for some pregnancy outcomes, there is more limited information available relating to neonatal and infant health outcomes. In particular, there is little information about the benefits and harms of progesterone in relation to long-term infant outcomes. Information is available from the follow-up of a single randomized trial related to long-term infant and childhood health outcomes. ${ }^{116}$ While this report indicates no statistically significant differences in health and developmental assessment at 2 years of age, only $60 \%$ of participants were available for assessment. ${ }^{116}$ Therefore, the longer-term follow-up of participants in randomized trials remains a priority.

Maternal outcomes after antenatal progesterone therapy have to date been poorly reported, including treatment side-effects, preferences of mode of administration and satisfaction with their pregnancy care. Further information is required on these important issues. ${ }^{135,136}$

Similarly, there is insufficient information available to date to be able to make valid recommendations about the optimal dose, route of administration, and gestational age at which to commence progesterone therapy, with utilisation of both vaginal and intramuscular preparations. There is considerable variation in the dose of progesterone administered, ranging from $90 \mathrm{mg}$ daily ${ }^{117}$ to $400 \mathrm{mg}$ daily ${ }^{132}$ when administered vaginally, and from $250 \mu \mathrm{g}$ weekly, ${ }^{105,123,124,137}$ to $250 \mu \mathrm{g}$ every 3 days, ${ }^{138} 341 \mu \mathrm{g}$ every 4 days, ${ }^{133}$ up to $1000 \mu \mathrm{g}$ weekly. ${ }^{139}$ The optimal time to commence therapy also varies considerably across studies, as does the duration of treatment. While the majority of studies commenced therapy in the mid-late second trimester at 24 to 28 weeks gestation, ${ }^{104,117,121,123,132,133,138}$ others commenced in the first trimester at the time of antenatal "booking", ${ }^{137}$ and still others from 16 weeks gestation. ${ }^{105,124,139}$ Similarly, there may be differences in the mechanism of action of natural progesterone (administered vaginally), compared 


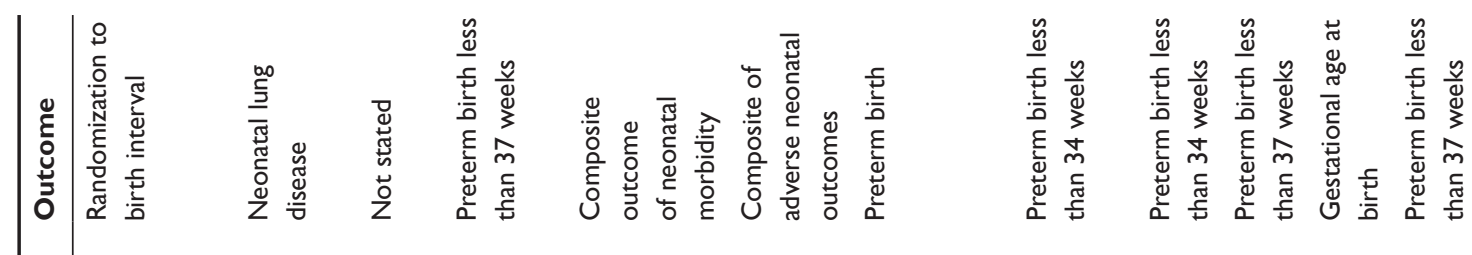

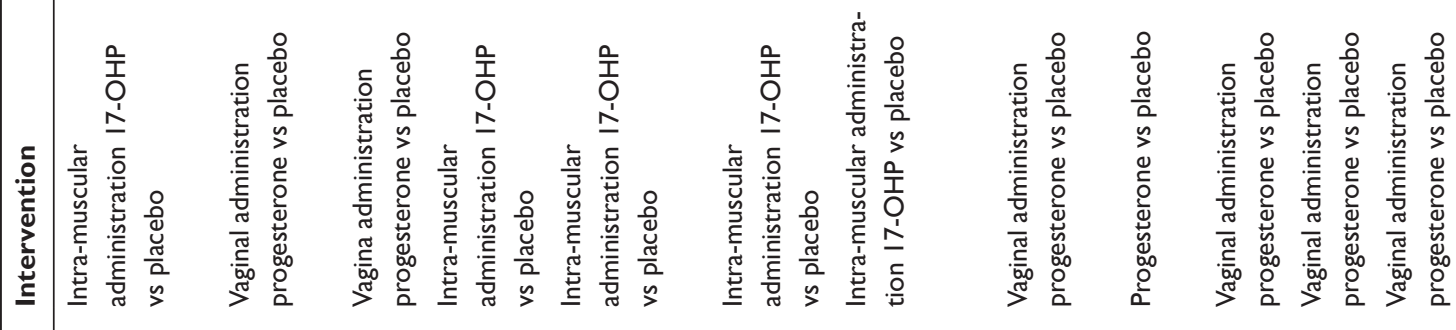

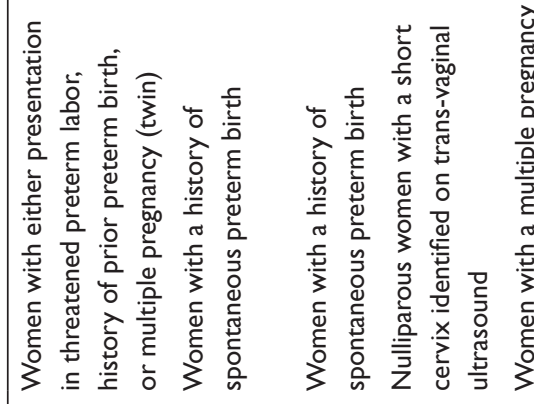

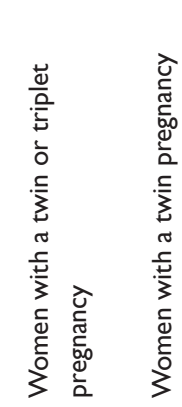

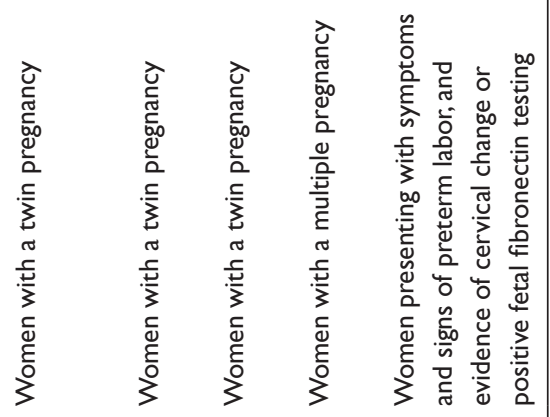
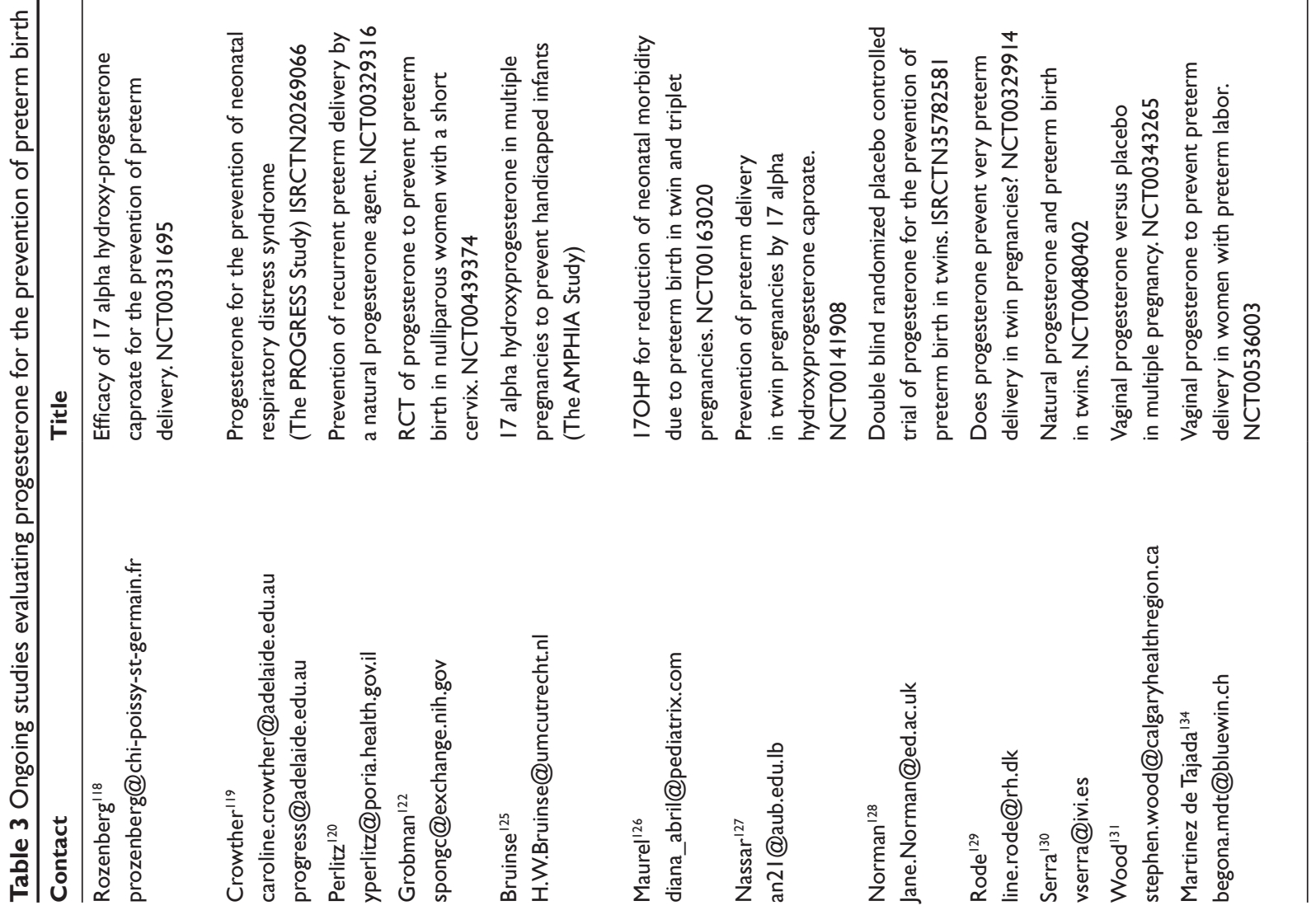
with the 17-hydroxyprogesterone caproate which has been most commonly administered to date as an intramuscular preparation.

\section{Conclusion}

Preterm birth remains a significant problem in obstetric care, affecting women and babies world-wide. There are considerable health consequences for infants born preterm, as well as economic consequences for the health care system, individuals, and their families. Improving health outcomes for preterm infants requires improvements in care for infants who are born preterm, or developing effective strategies that can reduce the chance of an infant being born preterm.

While the precise mechanism of both term and preterm labor remains unclear, progesterone plays an important role in the maintenance of pregnancy through the maintenance of uterine quiescence. Increasingly, there is information suggesting that progesterone may potentially mediate a woman's risk of preterm birth acting as an antiinflammatory agent.

Interest in the use of progesterone as a therapeutic agent to reduce the risk of preterm birth dates back to the 1960 s. Recent randomized trial reports have re-ignited the interest in progesterone for this indication. Evidence from randomized controlled trials and systematic reviews indicates a potential beneficial effect in the use of progesterone for some women considered to be at increased risk of preterm birth, primarily in the reduction in the risk of preterm birth before 34 weeks gestation. However, it remains unclear if the observed prolongation of pregnancy translates into improved health outcomes for the infant, as to date there is more limited information available about neonatal and longer-term infant health. Ongoing randomized trials, and in particular follow-up of participants into childhood, will contribute valuable information, and over time, help to establish the precise role of progesterone for women considered to be at increased risk of preterm birth.

\section{Disclosures}

The authors report no conflicts of interest.

\section{References}

1. World Health Organization (WHO): Recommended definitions, terminology and format for statistical tables related to the perinatal period and use of a new certificate for cause of perinatal deaths. Modifications recommended by FIGO October 14 1976. Acta Obstet Gynecol Scand. 1977;56:247-253.

2. Villar J, Abalos E, Carroli G, Giordano D, Wojdyla D, Piaggio G, et al. Heterogeneity of perinatal outcomes in the preterm delivery syndrome. Obstet Gynecol. 2004;104:78-87.
3. Steer P. The epidemiology of preterm labour. BJOG. 2005; 112(Suppl 1):1-3.

4. Wen SW, Smith G, Yang Q, Walker M. Epidemiology of preterm birth and neonatal outcome. Semin Fetal Neonatal Med. 2004;9(6): 429-435.

5. Kuehn BM. Groups take aim at US preterm birth rate. JAMA. 2006;296:2907-2908.

6. Langhoff-Roos J, Kesmodel U, Jacobsson B, Rasmussen S, Vogel I. Spontaneous preterm delivery in primiparous women at low risk in Denmark: population based study. BMJ. 2006;332:937-939.

7. Tracy SK, Tracy MB, Dean J, Laws PJ, Sullivan EA. Spontaneous preterm birth of liveborn infants in women at low risk in Australia over 10 years: a population-based study. BJOG. 2007;114:731-735.

8. Laws PJ, Graylon N, Sullivan EA. Australia's mothers and babies 2004 Sydney: Australian Institute of Health and Welfare, National Perinatal Statistics Unit; 2006.

9. Canadian Perinatal Health Report, 2003.

10. Blondel B, Macfarlane A, Gissler M, Breart G, Zeitlin J, Group $\mathrm{ftPS}$. Preterm birth and multiple pregnancy in European countries participating in the PERISTAT project. BJOG. 2006;113:528-535.

11. Smith GC, Shah I, Pell JP, Crossley JA, Dobbie R. Maternal obesity in early pregnancy and risk of spontaneous and elective preterm deliveries: a retrospective cohort study. Am J Public Health. 2007;97:157-162.

12. Martin JA, Hamilton BE, Sutton PD, Ventura SJ, Menacker F, Kirmeyer S. Births: Final Data for 2004. Natl Vital Stat Rep. 2006;55:1-140.

13. Burguet A, Kaminski M, Abraham-Lerat L, Schaal JP, Cambonie G, Fresson J, et al. The complex relationship between smoking in pregnancy and very preterm delivery. Results of the Epipage study. BJOG. 2004;111:258-265.

14. European community collaborative study of outcome of pregnancy between 22 and 28 weeks gestation. Working group on the very low birthweight infant. Lancet. 1990;336:782-784.

15. Chan K, Ohlsson A, Synnes A, Lee DSC, Chien L, Lee SK, et al. Survival, morbidity, and resource use of infants of 25 weeks gestational age or less. Am J Obstet Gynecol. 2001;185:220-226.

16. Kramer MS, Demissie K, Yang H, Platt RW, Sauve R, Liston R. The contribution of mild and moderate preterm birth to infant mortality. Fetal and infant health study group of the Canadian perinatal surveillance system. JAMA. 2000;284:843-849.

17. Mattison DR, Damus K, Fiore E, Petrini J, Alter C. Preterm delivery: a public health perspective. Paediatric and Perinatal Epidemiology. 2001;15(Suppl. 2):7-16.

18. Lefebvre F, Glorieux J, St. Laurent-Gagnon T. Neonatal survival and disability rate at age 18 months for infants born between 23 and 28 weeks of gestation. Am J Obstet Gynecol.1996;174:833-838.

19. Donoghue D, Bawden K, Cartwright D, Darlow B, Henderson-Smart D, Lancaster P. The report of the Australian and New Zealand Neonatal Network, 2000. Sydney: ANZNN; 2002.

20. O'Shea TM, Klinepeter KL, Goldstein DJ, Jackson BW, Dillard RG. Survival and developmental disability in infants with birthweights of 501 to $800 \mathrm{~g}$, born between 1979 and 1994. Pediatrics. 1997;100: 982-986.

21. Hack M, Friedman H, Fanaroff AA. Outcome of extremely low birthweight infants. Pediatrics. 1996;98:931-937.

22. Allen MC, Donohue PK, Dusman AE. The limit of viability - neonatal outcome of infants born at 22 to 25 weeks gestation. $N$ Engl J Med. 1993;329:1597-1601.

23. Kilpatrick SJ, Schleuter MA, Piecuch RE, Leonard CH, Rogido M, Sola A. Outcome of infants born at 24-26 weeks gestation: I. survival and cost. Obstet Gynecol. 1997;90:803-808.

24. Elder DE, Hagan R, Evans SF, Benninger HR, French NP. Hospital admissions in the first year of life in very preterm infants. J Paediatr Child Health. 1999;35(2):145-150.

25. Petrou S, Mehta Z, Hockley C, Cook-Mozaffari P, Henderson J, Goldacre M. The impact of preterm birth on hospital inpatient admissions and costs during the first 5 years of life. Pediatrics. 2003;112:1290-1297. 
26. Hack M, Fanaroff A. Outcome of extremely low birthweight and gestational age in the 1990s. Early Hum Dev. 1999;53:193-218.

27. Wood N, Marlow N, Costeloe K, Gibson A, Wilkinson A. Neurologic and developmental disability after extremely preterm birth. $N$ Engl J Med. 2000;343:378-384.

28. Stanley F. Survival and cerebral palsy in low birthweight infants: implications for perinatal care. Paediatr Perinat Epidemiol. 1992; 6:298-310.

29. Saigal S, Szatmari P, Rosenbaum P, Campbell D, King S. Cognitive abilities and school performance of extremely low birthweight children and matched term control children at age 8 years: a regional study. J Pediatr. 1991;118:751-760

30. Saigal S, Hoult L, Streiner D, Stoskopf BL, Rosenbaum P. School difficulties at adolescence in a regional cohort of children who were extremely low birth weight. Pediatrics. 2000;105:325-331.

31. Buck G, Msall M, Schisterman E, Lyon N, Rogers B. Extreme prematurity and school outcomes. Paediatr Perinat Epidemiol. 2000; 14:324-331.

32. Botting N, Powls A, Cooke RWI, Marlow N. Attention deficit hyperactivity disorders and other psychiatric outcomes in very low birthweight children at age 12 years. J Child Psychol Psychiatry. 1997;38:931-941

33. Hall A, McLeod A, Counsell C, Thomson L, Mutch L. School attainment, cognitive ability and motor function in a total Scottish very low birthweight population at 8 years - a controlled study. Dev Med Child Neurol. 1995;37:1037-1050.

34. Horwood LJ, Mogridge N, Darlow B. Cognitive, educational and behavioural outcomes at 7-8 years in a national very low birthweight cohort. Arch Dis Child Fetal Neonatal Ed. 1998;79: F12-F20.

35. The Scottish low birth-weight study: II language attainment, cognitive status and behavioural impairment at 4 years. Arch Dis Child. 1992;67:682-689.

36. Botting N, Powls A, Cooke RWI, Marlow N. Cognitive and educational outcome of very low birthweight children in early adolescence. Dev Med Child Neurol. 1998;40:652-660.

37. Hack M, Flannery DJ, Schluchter M, Cartar L, Borawski E, Klein N. Outcomes in young adulthood for very-low-birth-weight infants. N Engl J Med. 2002;346:149-157.

38. Hack M, Taylor HG, Drotar D, Schluchter M, Cartar L, Andreias L, et al. Chronic conditions, functional limitations, and special health care needs of school-aged children born with extremely low-birth-weight in the 1990s. JAMA. 2005;294:318-325.

39. Morrison JC. Preterm birth: a puzzle worth solving. Obstet Gynecol. 1990;76:5S-12S.

40. Gilbert WM, Nesbitt TS, Danielsen B. The cost of prematurity: Quantification by gestational age and birth weight. Obstet Gynecol. 2003;102:488-492.

41. Clements KM, Barfield WD, Femi Ayadi M, Wilber N. Preterm birthassociated cost of early intervention services: an analysis by gestational age. Pediatrics. 2007;119:e866-e874.

42. McCormick CM. The contribution of low birth weight to infant mortality and childhood morbidity. N Engl J Med. 1985;312:82-90.

43. Lang JM, Lieberman E, Cohen A. A comparison of risk factors for preterm labor and term small-for-gestational-age birth. Epidemiology. 1996; 7:369-376.

44. Scholl TO, Hediger ML, Belsky DH. Prenatal care and maternal health during adolescent pregnancy: A review and meta-analysis. J Adolesc Health. 1994;15:444-456.

45. Prysak M, Lorenz RP, Kisly A. Pregnancy outcome in nulliparous women 35 years and older. Obstet Gynecol. 1995;85:65-70.

46. Bakketeig LS, Hoffman HJ, Harley EE. The tendency to repeat gestational age and birth weight in successive births. Am J Obstet Gynecol. 1979;135:1086-1103.

47. Adams MM, Elam-Evans LD, Wilson HG, Gilbertz DA. Rates and factors associated with recurrence of preterm delivery. JAMA. 2000;283:1591-1596.
48. Bloom SL, Yost NP, McIntire DD, Leveno KJ. Recurrence of preterm birth in singleton and twin pregnancies. Obstet Gynecol. 2001;98: 379-385.

49. Berkowitz G, Papiernik E. Epidemiology of preterm birth. Epidemiol Rev. 1993;88:233-238.

50. Goldenberg RL, Rouse DJ. Prevention of premature birth. $N$ Engl J Med. 1998;339:313-320.

51. Kaminski M, Goujard J, Rumeau-Rouquette C. Prediction of low birthweight and prematurity by a multiple regression analysis with maternal characteristics known since the beginning of the pregnancy. Int J Epidemiol. 1973;2:195-204.

52. Papiernik E, Kaminski M. Multifactorial study of the risk of prematurity at 32 weeks of gestation: a study of the frequency of 30 predictive characteristics. J Perinat Med. 1974;2:30-36.

53. Robinson JN, Regan JA, Norwitz ER. The epidemiology of preterm labour. Semin Perinatol. 2001;25:204-214.

54. Kistka ZAF, Palomar L, Lee KA, Boslaugh SE, Wangler MF, Cole FS, et al. Racial disparity in the frequency of recurrence of preterm birth. Am J Obstet Gynecol. 2007;196:131.e1-131.e6.

55. Petrini J, Callaghan W, Klebanoff M, Green N, Lackritz E, Howse J, et al. Estimated effect of 17 alpha hydroxyprogesterone caproate on preterm birth in the United States. Obstet Gynecol. 2005;105: 267-272.

56. Mercer BM, Goldenberg RL, Moawad AH, Meis PJ, Iams JD, Das AF, et al. The preterm prediction study: effect of gestational age and cause of preterm birth on subsequent obstetric outcomes. Am J Obstet Gynecol. 1999;181(5 part 1):1216-1221.

57. Carr-Hill RA, Hall MH. The repitition of spontaneous preterm labour. BJOG. 1985;92:921-928.

58. Kliegman RM, Rottman CJ, Behrman RE. Strategies for the prevention of low birthweight. Am J Obstet Gynecol. 1990;162:1073-1083.

59. Hewitt BC, Newnham JP. A review of the obstetric and medical complications leading to the delivery of very low birth weight infants. Med J Aust. 1988;149:234-237.

60. McLaughlin KJ, Crowther CA, Vigneswaran P, Hancock E, Willson K. Who remains undelivered more than seven days after a single course of prenatal corticosteroids and gives birth at less than 34 weeks? Aust N Z J Obstet Gynaecol. 2002;42(4):353-357.

61. Moutquin JM. Socio-economic and psychosocial factors in the management and prevention of preterm labour. BJOG. 2003; 110(Suppl 20):56-60.

62. Challis JR, Matthews SG, Gibb W, Lye SJ. Endocrine and paracrine regulation of birth at term and preterm. Endocr Rev. 2000;21: 514-550.

63. Challis JR, Sloboda DM, Alfaidy N, Lye SJ, Gibb W, Patel FA, et al. Prostaglandins and mechanisms of preterm birth. Reproduction. 2002;124:1-17.

64. Lopez Bernal A. Mechanisms of labour - biochemical aspects. Br J Obstet Gynaecol. 2003;110(Suppl 20):39-45.

65. Astle S, Slater DM, Thornton S. The involvement of progesterone in the onset of human labour. Eur J Obstet Gynecol Reprod Biol. 2003;108:177-181.

66. Pepe GJ, Albrecht ED. Actions of placental and fetal adrenal steroid hormones in primate pregancy. Endocrine Rev. 1995;16:608-648.

67. Pieber D, Allport VC, Hills F, Johnson M, Bennett PR. Interactions between progesterone receptor isoforms in myometrial cells in human labour. Mol Hum Reprod. 2001;7:875-879.

68. Grazzini E, Guillon G, Mouillac B, Zingg HH. inhibition of oxytocin receptor function by direct binding of progesterone. Nature. 1998;392:509-512.

69. deZiegler D, Bulletti C, Fanchin R, Epiney M, Brioschi PA. Contractility of the nonpregnant uterus: the follicular phase. Ann NY Acad Sci. 2001;943:172-184.

70. Csapo AI. Progesterone "block”. Am J Anat. 1956;98:273-292.

71. Mesiano S. Myometrial progesterone responsiveness and the control of human parturition. J Soc Gynecol Investig. 2004;11: 193-202. 
72. Smith R, Mesiano S, McGrath S. Hormone trajectories leading to human birth. Regul Pept. 2002;108:159-164.

73. Haluska GJ, Wells TR, Hirst JJ, Brenner RM, Sadowsky DW, Novy MJ. Progesterone receptor localization and isoforms in myometrium, decidua, and fetal membranes from rhesus macaques: evidence for functional progesterone withdrawal at parturition. J Soc Gynecol Investig. 2002;9:125-136.

74. Condon JC, Jeyasuria P, Faust JM, Wilson JW, Mendelson CR. A decline in the levels of progesterone receptor coactivators in the pregnant uterus at term may antagonize pregesterone receptor function and contribute to the initiation of parturition. Proc Natl Acad Sci US A. 2003;100:9518-9523.

75. Jenkin G, Thorburn GD. Inhibition of progesterone secretion by a 3 beta hydroxysteroid dehydrogenase inhibitor in late pregnant sheep. Can J Physiol Pharmacol. 1985;63(2):136-142.

76. Block BS, Liggins GC, Creasy RK. Preterm delivery is not predicted by serial plasma estradiol or progesterone concentration measurements. Am J Obstet Gynecol. 1984;150:716-722.

77. Smit DA, Essed GG, deHaan J. Predictive value of uterine contractility and the serum levels of progesterone and oestrogens with regard to preterm labour. Gynecol Obstet Invest. 1984;18(5):252-263.

78. Romero R, Avila C, Brekus CA, Morotti R. The role of systemic and intrauterine infection in preterm parturition. Ann N Y Acad Sci. 1991;662:355-375.

79. McDonald H, Brocklehurst P, Parsons J. Antibiotics for treating bacterial vaginosis in pregnancy (Cochrane Review). The Cochrane Library. 2005(Issue 1 Cichester UK, John Wiley and Sons Ltd).

80. Gibb W, Challis JR. Mechanisms of term and preterm birth. J Obstet Gynaecol Can. 2002;24(11):874-883.

81. Smith R, Mesiano S, Nicholson R, Zakar T, Chan E, Bisits A, et al. Control of the length of gestation: lessons from women. In: Critchley $\mathrm{H}$, Bennett P, Thornton S, editors. Preterm Birth. London: RCOG Publications; 2004.

82. Elovitz M, Wang Z. Medroxyprogesterone acetate, but not progesterone, protects against inflammation-induced parturition and intrauterine fetal demise. Am J Obstet Gynecol. 2004;190:693-701.

83. Elovitz MA, Mrinalini C. The use of progestational agents for preterm birth: lessons from a mouse model. Am J Obstet Gynecol. 2006;195:1004-1010.

84. Elovitz MA, Mrinalini C. Can medroxyprogesterone acetate alter Toll-like receptor expression in a mouse model of intrauterine inflammation? Am J Obstet Gynecol. 2005;193(3 Part 2):1149-1155.

85. Shields AD, Wright J, Paonessa DJ, Gotkin J, Howard BC, Hoeldtke NJ, et al. Progesterone modulation of inflammatory cytokine production in a fetoplacental artery explant model. Am J Obstet Gynecol. 2005;193 (3 Part 2):1144-1148.

86. Gotkin JL, Celver J, McNutt P, Shields AD, Howard BC, Paonessa DJ, et al. Progesterone reduces lipopolysaccharide induced interleukin- 6 secretion in fetoplacental chorionic arteries, fractionated cord blood, and maternal mononuclear cells. Am J Obstet Gynecol. 2006;195: 1015-1019.

87. Abate A, Brigandi A, Costabile L, Abate FG, Balzano E, Perino M. 17-alpha-hydroxyprogesterone caproate and natural progesterone in assisted reproduction: a comparative study. Clin Exp Obstet Gynecol. 1997;24(4):190-192.

88. Levy T, Gurevitch S, Bar-Hava I, Ashkenazi J, Magazanik A, Homburg R, et al. Pharmacokinetics of natural progesterone administered in the form of a vaginal tablet. Hum Reprod. 1999;14: 606-610.

89. Penzias AS. Luteal phase support. Fertil Steril. 2002;77:318-323.

90. Tavaniotou A, Smitz J, Bourgain C, Devroey P. Comparison between different routes of progesterone administration as luteal phase support in infertility treatments. Hum Reprod Update. 2000;6:139-148.

91. Cicinelli E, Savino F, Cagnazzo I, Scorcia P. Comparative study of progesterone plasma levels after nasal spray and intramuscular administration of natural progesterone in menopausal women. Gynecol Obstet Invest. 1993;35(3):172-174.
92. Mircioio C, Perju A, Neagu A, Griu E, Calin G, Miron DS. Pharmacokinetics of progesterone in postmenopausal women: 1 . pharmacokinetics following intravaginal administration. Eur J Drug Metab Pharmacokinet. 1998;23:391-396.

93. Onsrud M, Paus E, Haug E, Kjorstad K. Intramuscular administration of hydroxyprogesterone caproate in patients with endometrial carcinoma. Pharmacokinetics and effects on adrenal function. Acta Obstet Gynecol Scand. 1985;64:519-523.

94. Raman-Wilms L, Tseng AL, Wighardt S, Einarson TR, Koren G. Fetal genital effects of first-trimester sex hormone exposure: a meta-analysis. Obstet Gynecol. 1995;85:141-149.

95. Schardein JL. Congenital abnormalities and hormones during pregnancy: a clinical reveiw. Teratology. 1980;22:251-270.

96. Crossley KJ, Nicol MB, Hirst JJ, Walker D, Thorburn GD. Suppression of arousal by progesterone in fetal sheep. Reprod Fertil Dev. 1997;9:767-773.

97. Nicol MB, Hirst JJ, Walker D. Effects of pregnanolone on behavioural parameters and the responses to $\mathrm{GABA}(\mathrm{A})$ receptor antagonists in the late gestation fetal sheep. Neuropharmacology. 1999;38:49-63.

98. Nicol MB, Hirst JJ, Walker D, Thorburn GD. Effect of alteration of maternal plasma progesterone concentrations on fetal behavioural state suring late gestation. J Endocrinol. 1997;152:379-386.

99. Dalton K. Antenatal progesterone and intelligence. Br J Psychiatry. 1968;114:1377-1382.

100. Dalton K. Prenatal progesterone and educational attainments. Br J Psychiatry. 1976;129:438-442.

101. Kester P, Green R, Finch SJ, Williams K. Prenatal "female hormone" administration in psychosexual development in males. Psychoneuroendocrinology. 1980;5:269-285.

102. Reinisch JM, Karow WG. Prenatal exposure to synthetic progestins and estrogens: effects on human development. Arch Sex Behav. 1977;6:257-288.

103. LeVine L. Habitual abortion. A controlled clinical study of progestational therapy. West $J$ Surg. 1964;72:30-36.

104. da Fonseca EB, Bittar RE, Carvalho MHB, Zugaib M. Prophylactic administration of progesterone by vaginal suppository to reduce the incidence of spontaneous preterm birth in women at increased risk: a randomized placebo-controlled double-blind study. Am J Obstet Gynecol. 2003;188:419-424.

105. Meis PJ, Klebanoff M, Thom E, Mitchell Pea. Prevention of recurrent preterm delivery by 17 -alpha hydroxyprogesterone caproate. $N \mathrm{Engl}$ J Med. 2003;348:2379-2385.

106. Coomarasamy A, Thangaratinam S, Gee H, Khan KS. Progesterone for the prevention of preterm birth: a critical evaluation of evidence. Eur J Obstet Gynecol Reprod Biol. 2006;129:111-118.

107. Dodd JM, Crowther CA, Cincotta R, Flenady VJ, Robinson JS Progesterone supplementation for the prevention of preterm birth: a systematic review. Acta Obstet Gynecol Scand. 2005;84:526-533.

108. Dodd JM, Flenady VJ, Cincotta R, Crowther CA. Progesterone for the prevention of preterm birth: A systematic review. Obstet Gynecol. 2008;112:127-134.

109. Dodd JM, Flenady VJ, Cincotta R, Crowther CA. Prenatal progesterone for prevention of preterm birth. Cochrane Database Syst Rev. 2009. In press.

110. Mackenzie R, Walker M, Armson A, Hannah ME. Progesterone for the prevention of preterm birth among women at increased risk: a systematic review and meta-analysis of randomized controlled trials. Am J Obstet Gynecol. 2006;194:1234-1242.

111. Sanchez-Ramos L, Kaunitz AM, Delke I. Progestational agents to prevent preterm birth: a meta-analysis of randomized controlled trials. Am J Obstet Gynecol. 2005;105:273-279.

112. How HY, Sibai BM. Progesterone for the prevention of preterm birth: indications, when to initiate, efficacy and safety. Ther Clin Risk Manag. 2009;5:55-64.

113. Jayasooriva GS, Lamont RF. The use of progesterone and other progestational agents to prevent spontaneous preterm labour and preterm birth. Expert Opin Pharmacother. 2009;10(6):1007-1016. 
114. O'Brien JM, Lewis DF. Progestins for the prevention of spontaneous preterm birth: review and implications of recent studies. $J$ Reprod Med. 2009;54(2):73-87.

115. Tita AT, Rouse DJ. Progesterone for preterm birth prevention: an evolving intervention. Am J Obstet Gynecol. 2009;200:219-224.

116. Northen AT, Norman GS, Anderson K, Moseley L, Divito M, Cotroneo M, et al. Follow-up of children exposed in utero to 17 alphahydroxyprogesterone caproate compared with placebo. Obstet Gynecol. 2007;110:865-872.

117. O'Brien JM, Adair CD, Lewis DF, Hall DR, Defranco EA, Fusey S, et al. Progesterone vaginal gel for the reduction of recurrent preterm birth: primary results from a randomized double blind placebo controlled trial. Ultrasound Obstet Gynecol. 2007;30:687-696.

118. Rozenberg P. Efficacy of 17 alpha-hydroxyprogesterone caproate for the prevention of preterm delivery. Available at http://controlledtrials. com. Accessed 2007.

119. Crowther CA, Dodd JM, McPhee AJ, Flenady V. Australasian Collaborative Trial of Vaginal Progesterone Therapy (The PROGRESS Trial) Available at http://controlledtrials.com. Accessed 2007.

120. Perlitz Y. Prevention of recurrent preterm delivery by a natural progesterone agent. Available at http://controlledtrials.com. Accessed 2007.

121. Fonseca EB, Celik E, Parra M, Singh M, Nicolaides KH. Progesterone and the risk of preterm birth among women with a short cervix. $N E n g l$ J Med. 2007;357:462-469.

122. Grobman W. RCT of progesterone to prevent preterm birth in nulliparous women with a short cervix. Available at http:// controlledtrials.com. Accessed 2007.

123. Hartikainen-Sorri AL, Kauppila A, Tuimala R. Inefficacy of 17 alpha hydroxyprogesterone caproate in the prevention of prematurity in twin pregnancy. Obstet Gynecol. 1980;56:692-695.

124. Rouse DJ, Caritis SN, Peaceman AM, Sciscione A, Thom EA, Spong CY, et al. A trial of 17 Alpha-hydroxyprogesterone caproate to prevent prematurity in twins. $N$ Engl J Med. 2007;357: 454-461.

125. Bruinse HW. 17 alpha hydroxyprogesterone in multiple pregnancies to prevent handicapped infants (The AMPHIA Study). Available at http://www.controlledtrials.com. Accessed 2007.
126. Maurel K, Combs A. 17OHP for reduction of neonatal morbidity due to preterm birth (PTB) in twin and triplet pregnancies. Available at http://controlledtrials.com. Accessed 2007.

127. Nassar A. Prevention of preterm delivery in twin pregnancies by 17 alpha hydroxyprogesterone caproate. Available at http:// controlledtrials.com. Accessed 2007.

128. Norman J. Double blind randomised placebo controlled trial of progesterone for the prevention of preterm birth. Available at http://controlledtrials.com. Accessed 2007.

129. Rode L. The PREDICT study. Available at http://controlledtrials.com. Accessed 2007.

130. Serra V. Natural progesterone and preterm birth in twins. Available at http://controlledtrials.com. Accessed 2007.

131. Wood S. Vaginal progesterone versus placebo in multiple pregnancy. Available at http://controlledtrials.com. Accessed 2007.

132. Borna S, Sahabi N. Progesterone for maintenance tocolytic therapy after threatened preterm labour: A randomised controlled trial. Aust N Z J Obstet Gynaecol. 2008;48:58-63.

133. Facchinetti F, Paganelli S, Comitini G, Dante G, Volpe A. Cervical length changes during preterm cervical ripening: effects of 17-alpha-hydroxyprogesterone caproate. Am J Obstet Gynecol. 2007;196:453e1-453e4.

134. Matrinez de Tajada B. Vaginal progesterone to prevent preterm delivery in women with preterm labor. Available at http://controlledtrials.com. Accessed 2007.

135. Greene MF. Progesterone and preterm delivery - deja vu all over again. N Engl J Med. 2003;348:2453-2455.

136. Iams JD. Supplemental progesterone to prevent preterm birth. Am J Obstet Gynecol. 2003;188(2):303.

137. Johnson JWC, Austin KL, Jones GS, Davis GH, King TM. Efficacy of 17 alpha hydroxyprogesterone caproate in the prevention of premature labor. $N$ Engl J Med. 1975;293:675-680.

138. Papiernik-Berkhauer E. Etude en double aveugle d'un medicament prevenant la survenue prematuree de l'accouchement chez les femmes a risque eleve d'accouchement premature. Edition Schering Serie IV. 1970;3:65-68.

139. Hauth JC, Gilstrap LC, Brekken AL, Hauth JM. The effect of 17 alpha hydroxyprogesterone caproate on pregnancy outcome in an active-duty military population. Am J Obstet Gynecol. 1983;146:187-190.
International Journal of Women's Health

\section{Publish your work in this journal}

The International Journal of Women's Health is an international, peerreviewed open-access journal publishing original research, reports, reviews and commentaries on all aspects of women's healthcare including gynaecology, obstetrics, and breast cancer. Subject areas include: Chronic conditions (migraine headaches, arthritis, osteoporosis);

\section{Dovepress}

Endocrine and autoimmune syndromes; Sexual and reproductive health; Psychological and psychosocial conditions. The manuscript management system is completely online and includes a very quick and fair peer-review system. Visit http://www.dovepress.com/ testimonials.php to read real quotes from published authors. 